\title{
THE MEANING OF EVOLUTION
}

A Study of the History of Life and of Its Significance for Man 
This page intentionally left blank 


\section{THE}

MEANING

OF

\section{EVOLUTION}

A Study of the History of Life and of

Its Significance for Man

by

\section{GEORGE GAYLORD SIMPSON}

YALE UNIVERSITY PRESS, NEW HAVEN AND LONDON 
COPYRIGHT (C) I 949 BY YALE UNIVERSITY PRESS. REVISED EDITION COPYRIOHT (C) 1967 BY YALE UNIVERSITY.

ALL RIGHTS RESERVED. THIS BOOK MAY NOT BE REPRODUCED, IN WHOLE OR IN PART, IN ANY FORM (BEYOND THAT COPYING PERMITTED BY SECTIONS IO7 AND IO8 OF THE U.S. COPYRIGHT LAW AND EXCEPT BY REVIEWERS FOR THE PUBLIC PRESS), WITHOUT WRITTEN PERMISSION FROM THE PUBLIS HERS.

ISBN : 0-300-00952-6 (CLOTH), 0-300-00229-7 (PAPER)

DESIGNED BY BEVERLY KRUGER, SET IN BASKERVILLE TYPE, AND PRINTED IN THE UNITED STATES OF AMERICA BY BOOKCRAFTERS, INC., FREDERICKSBURG, VIRGINIA.

$\begin{array}{llllllll}20 & 19 & 18 & 17 & 16 & 15 & 14 & 13\end{array}$ 